\title{
Integrated Management of Damping-off, Root and/or Stem Rot Diseases of Chickpea and Efficacy of the Suggested Formula
}

\author{
Montaser Fawzy ABDEL-MONAIM \\ Plant Pathology Research Institute, Agriculture Research Center, Giza, Egypt; fowzy_2008@yahoo.com
}

\begin{abstract}
Eleven fungal isolates were isolated from naturally infected chickpea roots collected from different locations in New Valley Governorate (Egypt). The isolated fungi were purified and identified as Rhizoctonia solani ( 5 isolates), Fusarium solani (4 isolates) and Sclerotinia sclerotiorum (2 isolates). The isolated fungi proved their pathogenicity on cv. 'Giza 3'. Response of chickpea cvs. 'Giza 1', 'Giza 2,' 'Giza 3,' 'Giza 4,' 'Giza 88,' 'Giza 195', 'Giza 531' to infection by the tested fungi was significantly varied. 'Giza 1' was the most resistant one followed by 'Giza 531', while the other tested cvs. were highly susceptible. Seven biocontrol agents, namely Bacillus subtilis, B. megaterium, B. cereus, Trichoderma viride, T. harzianum, Aspergillus sp., Penicillium sp. isolated from chickpea rhizosphere, were tested for their antagonistic action against the tested pathogens. B. subtilis isolate BSM1, B. megaterium isolate TVM5, T. viride isolate TVM2 and T. harzianum isolate THM4 were the most antagonistic ones to the tested fungi in vitro, while the other isolates were moderate or weak antagonists. The most antagonistic isolates as well as the commercial biocide Rhizo-N were applied as seed treatment for controlling damping-off, root and/or stem rot diseases caused by the tested fungi under greenhouse conditions. The obtained data showed that all tested antagonistic isolates were able to cause significant reduction of damping-off, root and/or stem rot diseases in chickpea plants. T. viride (isolate TVM2) and B. megaterium (isolate BMM5) proved to be the most effective isolates for controlling the diseases. Under field condition, the obtained data indicated that all the tested antagonistic isolates significantly reduced dampingoff, root and/or stem rot. T. viride (isolate TVM2) and B. megaterium (isolate BMM5) recorded the highest reduction of damping-off, root and/or stem rot in all sowing dates. Sowing of treated seeds with bioagents in first of November gave the highest protection against root diseases in chickpea. The reduction in damping-off, root and/or stem rot severity was significantly reflected on the produced seed yield. In this respect, seeds previously treated with T. viride (TVM2) produced the highest seed yield in all sowing dates followed by seed treated with B. megaterium (TVM5). First of November was the best sowing date to reduce these diseases and to increase seed yield/fed. On the other hand, the antagonistic isolates isolated from chickpea rhizosphere, were most active than the commercial biocide Rhizo-N in reducing chickpea root diseases and increase of seed yield in greenhouse and field conditions.
\end{abstract}

Keywords: chickpea, Fusarium solani, intergraded control, resistant cultivar, Rbizoctonia solani, Sclerotinia sclerotiorum, sowing date, Trichoderma and Bacillus

\section{Introduction}

Chickpea (Cicer arietinum L.) is the second most important pulse crop in the world after beans (Phaseolus vulgaris L.) (Anonymous, 2005). In addition to its importance a source of human food and animal feed, it also helps in the management of soil fertility, particularly in dry lands. Soilborne fungi, Fusarium eumartii, F. oxysporum f. sp. ciceris, F. solani, Pythium ultimum, Rhizoctonia solani, Scleritium rolfsii, Sclerotinia sclerotiorum and Verticillium albo-atrum are reported to be the most pathogenic fungi in chickpea causing damping -off, root and/or stem rot and wilt diseases (Nene and Reddy, 1987). In Egypt, many authors reported that chickpea is attacked with many soil borne fungi, i.e Fusarium spp., Rhizoctonia solani, Sclerotinia sclerotiorum, Pythium spp., Macrophomina phaseolina causing damping -off, root and stem rot diseases (Khalil, 2007; Rahhal et al., 2000).

Different fungicides and soil fumigants are currently used to control soil borne plant pathogens. However, many of these compounds proved to be quite toxic to the environment and to the ground water. Methyl bromide is a good example for a very efficient soil fumigant that has a great impact on the environment and has been recently phased out due to the public concern and international agreements.

The use of antagonistic microorganisms against $R$. solani, F. solani and S. sclerotiorum have been investigated as one of the alternative control methods. Both Trichoderma spp. and Bacillus spp are wide spread throughout the world and have been recognized as the most successful biocontrol agents for soil borne pathogens. Several modes of action of the efficiency bioagents on reducing plant diseases have been described, including competition for nutrients, antibiosis, induced resistance, mycoparasitism, plant growth promotion and rhizosphere colonization capability (Bailey et al., 2008; Hassanein et al., 2006; Siddiqui and Akhtar, 2007).

Also, cultural practices, such as planting date proved to be very effective in reducing fungal attack to plants, but 
they are insufficient under high disease pressure, especially when weather conditions are particularly conductive to disease development (Khalil, 2007). The use of resistant cultivars appears to be the most practical and economically efficient measure for management of root diseases of chickpea and is also a key component in IDM programs (Jiménez-Díaz et al., 1998).

The objective of this research was to identify the benefits of integrating several control measures including choice of sowing date, partially resistant cultivars, and biological control, which previously were shown to be useful in the management of damping-off, root rot and/or stem rot of chickpeas when used individually. Studies were conducted during two consecutive years in naturally infested field micro-plots in research farm of El- Kharga Agric. Res. Station, New Valley governorate that have been used in this work to (i) select resistant chickpea cultivars; (ii) select bacteria and fungi obtained from the chickpea rhizosphere with antagonistic activity against tested fungi; (iii) determine the ability of selected bacteria and fungi to suppress damping-off, root rot and stem rot diseases caused by a highly virulent isolates of $R$. solani, F. solani and $S$. sclerotiorum and determine suitable sowing date that give the best control of root diseases and increase of seed yield.

\section{Materials and methods}

Isolation, purification and identification offungi causing root and stem rot diseases of chickpea

Chickpea plants infected with root and stem rot were collected from different locations in New Valley Governorate, Egypt. Infected roots and stems were washed with running tap water to remove any soil remains, and then cut into small pieces before being dipped in sodium hypochlorite solution (2\%) for two minutes for surface sterilization. These plant parts were then passed through changes of distilled water, dried between sterilized filter paper, then placed on PDA medium with and without antibiotics. The plates were incubated at $25^{\circ} \mathrm{C} \pm 1$ and scanned daily for fungal development.

Preliminary microscopic examination of the fungi isolated showed that they could be classified under three genera, i.e. Fusarium, Rhizoctonia and Sclerotinia. Fusarium isolates were purified by plating single conidial spores (Booth, 1985) while, Rbizoctonia solani and Sclerotinia sclerotiorum were purified using the hyphal tip technique (Dhingra and Sinclair, 1985). Representative isolates were maintained on PDA slants for further studies. Isolated fungi were identified according to their morphological features as described by Booth (1985), Dhingra and Sinclair (1985) and Barnett and Hunter (1986).

\section{Pathogenicity tests of the isolated fungi}

Conical flasks, each containing $100 \mathrm{~g}$ barley grains and about $100 \mathrm{ml}$ tap water, were autoclaved at $1.5 \mathrm{~kg} / \mathrm{cm}^{2}$ pressure for $30 \mathrm{~min}$. They were inoculated with $0.7 \mathrm{~cm}$ di- ameter fungal discs from the fungal isolates and incubated at $25^{\circ} \mathrm{C} \pm 1$ for two weeks. Soil infestation was performed by mixing in about $100 \mathrm{~g}$ of inoculum with the soil in each pot (rate of 2\%) and pots were then irrigated. Sterilized uninoculated barley grains were added to the soil at the same rate and used as control. Seven days after soil infestation, eight seeds of susceptible cultivar cv. 'Giza 3' (Khalil, 2007) were sown in each pot and pots were irrigated directly. Four replicated pots were used for each treatment. The percentage of damping -off was recorded one month after sowing. Three months after planting, chickpea plants were pulled-off from the soil, washed thoroughly to remove soil debris. Root and stem rot were assessed according to disease index: $0=$ roots or stems without discoloration (no infection), $1=1-20 \%, 2=21-40 \%, 3=41-75 \%, 4=76$ $100 \%$ discoloration root or stem mass and $5=$ completely dead plants including pre-or post emergence damping- off or old plants for each replicate. For each replicate a disease severity index (DSI) similar to that one described by Liu et al. (1995) was calculated as follows:

\section{$\mathrm{DSI}=\Sigma \mathrm{d} /\left(\mathrm{d}_{\max } \mathrm{X} \mathrm{n}\right) \mathrm{X} 100$}

Whereas:

$\mathbf{d}$ is the disease rating of each plant, $\mathbf{d}$ max is the maximum disease rating and $\mathbf{n}$ is the total number of plants examined in each replicate.

Re-isolation was carried out from the diseased plants to fulfill Koch's pustules and the developing fungi were compared with the original isolates.

Evaluation of chickpea cultivars to infection with root and stem rot pathogens

Response of seven chickpea cultivars namely 'Giza 1' 'Giza 2', 'Giza 3', 'Giza 4', 'Giza 88, 'Giza 195', 'Giza 531' (obtained from Legume Crop Research Department, Field Crop Research Institute, Agric. Res. Center, Giza) to infection with highly pathogenic isolates $(R$. solani isolate $\mathrm{C} 1, F$ solani isolate $\mathrm{C} 6$ and $S$. sclerotiorum isolate C11) were used in this study. The tested cultivars were grown in plastic pots containing sterilized soil and infested with the pathogenic fungal isolates individually. Four replicated pots were used for each treatment and each pot was planted with 8 seeds. The inocula of the tested fungi were prepared and applied similarly as was done in the pathogenicity test.

Data were recorded for damping-off and root/stem rot after 30 and 90 days of sowing as above mentioned in pathogenicity tests.

\section{Isolation, purification and identification of antagonistic organisms}

Antagonistic microorganisms were isolated from soil rhizosphere samples of healthy chickpea plants producing area at New Valley governorate, Egypt. The used bioagents were isolated on selected medium according to the methods recommended by Turner $e t$ al. (1998). The isolated antagonists were purified by using single spores and/or single 
82

colonies techniques described by Landa et al. (2001). The fungal isolates were identified as Trichoderma harzianum, T. viride, Aspergillus sp. and Penicillium sp. on the basis of their morphological characters (Barnett and Hunter, 1986) and the bacterial isolates were identified as Bacillus spp according to the morphological and biochemical activities in standard tests (Sneath et al., 1986).

\section{In vitro screening test for antagonistic effect}

The tested isolates of antagonistic fungi were grown on PDA medium at $25^{\circ} \mathrm{C} \pm 1$ for 6 - days and used as inocula. Disks from each isolate of antagonistic fungi $(7 \mathrm{~mm}$ in diameter) were inoculated on PDA medium on one side of Petri plate and the opposite side was inoculated by pathogenic fungul inoculums ( $R$. solani, F. solani and/or $S$. sclerotiorum) inocula (Larkin and Fravel, 1998). While in case of Bacillus spp isolates, each isolate was streaked at one side on PDA medium in plates and incubated for 24 hrs. at $25^{\circ} \mathrm{C} \pm 1$, then one disc ( $7 \mathrm{~mm}$ in diameter) of any of the pathogenic isolates was placed on the opposite side (Kaur et al., 2007). Four replicates were used for each treatment. The inoculated plates with pathogenic fungi only were used as control. After 7 days incubation at $25^{\circ} \mathrm{C} \pm 1$, linear growth of pathogenic isolates in all treatments was recorded. The decrease of percentage that occurred in linear growth of the pathogenic fungi was determined at the end of the experiment using formula suggested by Fokemma (1973) as follows:

\section{Reduction in linear growth $=[(\mathrm{R} 1-\mathrm{R} 2) / \mathrm{R} 1] \times \mathbf{x} 100$ \\ Where:}

$\mathrm{R} 1=$ the radius of normal growth in control plates;

$\mathrm{R} 2=$ the radius of inhibited growth.

The highly antagonistic isolates of $B$. subtilis isolate 1 (BSM1), B. megaterium isolate 5 (BMM5), T. viride isolate 2 (TVM2) and T. harzianum isolate 4 (THM4) were selected and used in further studies.

\section{Preparation of formulated antagonistic fungi and bacteria}

Antagonistic bacterial inoculum used for treatment of chickpea seeds cv. 'Giza 3' were produced as described by Landa et al. (2001). Inoculum of B. subtilis (BSM1) and B. megaterium (BSM5) were produced in $100 \mathrm{ml}$ of Potato Dextrose Broth (PDB) medium ( $\mathrm{pH} 7$ ) in $250 \mathrm{ml}$ conical flasks, on an orbital shaker at $125 \mathrm{rpm}$ and $28^{\circ} \mathrm{C}$ for 3 days. Bacterial cells were harvested by centrifugation $(10,000 \times$ $g$ for $20 \mathrm{~min}$ ) and washed twice with sterile $0.1 \mathrm{M} \mathrm{MgSO} 4$. Bacterial concentration in the suspension was adjusted to proximately $5 \times 10^{8}$ cells per $\mathrm{ml}$ by measuring absorbance at $600 \mathrm{~nm}(A 600)$ in a spectrophotometer and using standard curves for each bacterial isolate. Inocula of $T$. viride (TVM2) and T. harzianum (THM4) were prepared as described by Sallam et al. (2008) as follows: the tested isolates of Trichoderma spp. were grown in $1000 \mathrm{~mL}$ conical flasks, each containing $250 \mathrm{~g}$ vermiculate soil (El-Halal Company, El-Khatatpa, Egypt). 250 g wheat bran and 250 $\mathrm{ml} \mathrm{Czapex's} \mathrm{medium} \mathrm{and} \mathrm{autoclaved} \mathrm{for} 20 \mathrm{~min}$ at $121^{\circ} \mathrm{C}$. on two consecutive days. After 25 days of incubation period, contents of flasks were transferred to plastic plates under sterilized conditions, left to air dry then mixed in a blender to become powder and kept in sterilized polyethylene bags at room temperature until used colony forming units in all formulae of Trichoderma spp was adjusted to $3 \mathrm{x}$ $10^{7} \mathrm{cfu} / \mathrm{g}$. (Sallam et al., 2008)

Effects of seed treatment with biocontrol agents on chickpea damping-of and root and /or stem rot diseases under greenhouse conditions

In this experiment, cultivar 'Giza 3', the highest susceptible cultivar to infection by pathogenic fungal isolates was used to study the effect of bioagent isolates on dampingoff and root and/or stem rot diseases in chickpea.

Before treatment with biocontrol agents, seeds were surface disinfested in $2 \% \mathrm{NaOCl}$ for $3 \mathrm{~min}$, washed three times in sterilized distilled water, and dried between sterilized filter paper layers. Seeds were treated at the time with a bacterial bioagents isolates $(10 \mathrm{~mL}$ of bacterial biocontrol agent suspension in $0.1 \mathrm{M} \mathrm{MgSO}_{4}$ and $0.5 \%$ carboxymethyl cellulose per $100 \mathrm{~g}$ of chickpea seeds) and fungal bioagents isolates (10 $\mathrm{g}$ of Trichoderma prepared inoculum and $10 \mathrm{~mL}$ of $0.5 \%$ carboxymethyl cellulose per 100 gm chickpea seeds) as well as seeds treated with bio commercial product Rhizo-N (B. subtilis-produced by ElNaser of Fertilizers and Biotic Fungicides Co., El-Sadat, Egypt) used as compression at $4 \mathrm{~g} / \mathrm{kg}$ seeds.

Chickpea treated seeds with bioagents were sown in sterilized soil infested with any of the tested fungi as mentioned before at $2 \%(\mathrm{w} / \mathrm{w})$. Untreated chickpea seeds with biocontrol were sown in infested soil used as a control. Four replicates were used; each replicate consisted of three pots ( 8 seeds/pot). Data were recorded for damping-off, root and/or stem rot after 30 and 90 days of sowing, respectively.

\section{Integrated control of root and stem rot in chickpea plants under field conditions}

Field experiments were conducted at the Experimental Farm of El-Kharga Agric. Res. Station, New Valley Governorate, Egypt in 2008-2009 and 2009-2010 growing seasons. The experimental layout was split plot design with four replications. The field plots $\left(10.5 \mathrm{~m}^{2}\right)$ consisted of 6 rows of $3.5 \mathrm{~m}$ long and $0.60 \mathrm{~m}$ in between. Chickpea seeds cv. 'Giza 1' (resistant cultivar) were treated with fungal and bacterial bioagents isolates as mentioned before as well as seeds treated with the bio commercial product Rizo $-\mathrm{N}$ were used as compression and grown in holes at the rate of 2 seeds/hole with $10 \mathrm{~cm}$ apart between holes ( 35 holes/ row). Untreated seeds were sown as a control treatment. All treatments were sown in three sowing dates 1 st $\mathrm{Oc}$ tober, $1^{\text {st }}$ November, $1^{\text {st }}$ December in seasons 2008/2009 and $2009 / 2010$. All the agricultural practices were applied as usual. 
Data were recorded as damping-off, root and/or stem rot after 30 and 90 days. At the end of experiment, seed yield was harvested, weighed and calculated as $\mathrm{kg} / \mathrm{fed}$.

\section{Statistical analysis}

In all experiments the least significant difference (LSD) at 0.05 confidences was determined according to Gomez and Gomez (1984).

\section{Results}

Isolation, identification of the causal fungi and pathogenicity tests

Eleven isolates were obtained from naturally infected chickpea plants collected from different locations in New Valley governorate. The isolated fungi were consisting of isolates belonging to the genera Rhizoctonia, Fusarium and Sclerotinia as shown by preliminary microscopic examination. The isolates were identified as $R$. solani, F. solani, and S. sclerotiorum respectively. Data in Tab. 1 show that the highest percentage of pre-emergence damping-off was recorded by $R$. solani isolate $\mathrm{C} 1$ (50\%) followed by $R$. solani isolate $\mathrm{C} 3$ then $F$. solani isolate $\mathrm{C} 6$ and $S$. sclerotiorum isolate C11, being 40.6, 34.4 and $40.6 \%$, respectively. While moderate pre-emergence damping-off (18.8-31.3\%) occurred by $R$. solani isolates $\mathrm{C} 2, \mathrm{C} 4$ and $\mathrm{C} 5, F$ solani isolates $\mathrm{C} 7$ and $\mathrm{C} 8$ and $S$. sclerotiorum isolate C10. F. solani isolate C9 showed weak ability to cause pre-emergence damping-off (9.4\%). On the other hand, $R$. solani isolates

Tab. 1. Pathogenicity tests of fungal isolates obtained from naturally diseased chickpea plants (cv. 'Giza 3')

\begin{tabular}{|c|c|c|c|c|}
\hline \multirow[b]{2}{*}{ Isolates } & \multicolumn{3}{|c|}{ \% Damping-off } & \multirow{2}{*}{$\begin{array}{l}\% \text { Dead } \\
\text { plants }\end{array}$} \\
\hline & $\begin{array}{c}\text { Pre- } \\
\text { emergence }^{a}\end{array}$ & $\begin{array}{c}\text { Post- } \\
\text { emergence }^{\mathrm{b}}\end{array}$ & Total & \\
\hline \multicolumn{5}{|c|}{ Rhizoctonia solani } \\
\hline $\mathrm{C} 1$ & $50.0^{\mathrm{d}}$ & 21.9 & 71.9 & 25.0 \\
\hline $\mathrm{C} 2$ & 31.3 & 15.6 & 46.9 & 18.3 \\
\hline C3 & 40.6 & 21.9 & 62.5 & 17.4 \\
\hline $\mathrm{C} 4$ & 18.8 & 9.4 & 28.2 & 9.2 \\
\hline C5 & 25.0 & 15.6 & 40.6 & 13.6 \\
\hline Mean & 33.14 & 16.88 & 50.02 & 16.70 \\
\hline \multicolumn{5}{|c|}{ Fusarium solani } \\
\hline C6 & 34.4 & 21.9 & 56.3 & 31.0 \\
\hline $\mathrm{C} 7$ & 25.0 & 6.3 & 31.3 & 18.4 \\
\hline $\mathrm{C} 8$ & 25.0 & 9.4 & 34.4 & 16.3 \\
\hline C9 & 9.4 & 3.1 & 12.5 & 9.9 \\
\hline Mean & 23.45 & 10.18 & 33.63 & 18.9 \\
\hline \multicolumn{5}{|c|}{ Sclerotinia sclerotiorum } \\
\hline $\mathrm{C} 10$ & 25.0 & 9.4 & 34.4 & 16.3 \\
\hline C11 & 40.6 & 12.5 & 53.1 & 29.4 \\
\hline Mean & 31.3 & 12.5 & 43.8 & 22.85 \\
\hline LSD at 0.05 & 2.4 & 2.0 & 3.6 & 1.6 \\
\hline
\end{tabular}

a, b , c Assessed 15, 30, 90 days after sawing, respectively; ${ }^{\mathrm{c}}$ Dead plants, \% due to infection by root rot and/or stem rot; ${ }^{\mathrm{d}}$ Values are means of 4 replicates of $\mathrm{C} 1$ and $\mathrm{C} 3$ and $F$. solani isolate $\mathrm{C} 6$ caused the highest percentage of post emergence damping-off (21.9\%) followed by $R$. solani isolate C5 (15.6\%). While, the other isolates caused 3.1-12.5\% post-emergence damping-off.

F. solani isolate $\mathrm{C} 6$ caused the highest root rot severity (31.0\%) followed by S. sclerotiorum isolate C11 (29.4\%). Isolates $R$. solani $\mathrm{C} 4$ and $F$. solani $\mathrm{C} 9$ were too weak ones to cause root rot symptoms ( 9.2 and $9.9 \%$, respectively).

It could be noted from these results that $R$. solani isolate $\mathrm{C} 1, F$. solani isolate $\mathrm{C} 6$ and $S$. sclerotiorum $\mathrm{C} 11$ were the highest pathogenic isolates for causing damping-off and root/stem rot in chickpea plants.

Evaluation of chickpea cultivars to infection with damping-off, root and/or stem rot pathogens

Response of chickpea cultivars to $R$. solani, F. solani and S. sclerotiorum infection significantly varied (Tab. 2). Cultivar 'Giza 1' was resistant to infection by any of the tested pathogenic fungi followed by cv. 'Giza 531', compared to the other cultivars. The percentages of dampingoff and root rot caused by $R$. solani were 18.8, 11.2\% and 21.9, $12.6 \%$ in both cultivars, respectively. While, F. solani caused 15.6 and $21.9 \%$ damping-off and $14.0,15.4 \%$ root rot in case of cvs. 'Giza 1' and 'Giza 531', respectively. $S$. sclerotiorum caused 12.5 and $15.6 \%$ damping-off and 14.0, $15.5 \%$ stem rot in both tested cultivars, respectively. On the other hand, the other tested cultivars were highly susceptible or susceptible towards infection by $R$. solani, $F$. solani and S. sclerotiorum. Cv. 'Giza 3' showed the highest susceptibility to infection by all the tested fungi. Also, the obtained data showed that $R$. solani and $S$. sclerotiorum were more pathogenic than $F$. solani.

\section{Selection of antagonistic organisms for ability to inhibit} in vitro growth of pathogenic fungi

Antagonistic effect of 8 bacterial isolates and 9 fungal isolates isolated from the rhizosphere of chickpea plants was tested against $R$. solani, F. solani and S. sclerotiorum in dual culture under in vitro conditions.

\section{A) Antagonistic bacteria}

Data in Tab. 3 shows that all antagonistic bacterial isolates were able to inhibit the growth of $R$. solani, F. solani and $S$. sclerotiorum, with some being stronger than others. Isolates $B$. subtilis BSM1 and B. megaterium BMM5 were found to be the most potent antagonistic bacteria to all pathogenic fungi. However, the other antagonistic bacterial isolates were moderate or weak. B. subtilis isolate BSM1 inhibited the growth of R. solani, F. solani and $S$. sclerotiorum by $40.2,53.5$ and $50.1 \%$, respectively. While, $B$. megaterium isolate BMM5 inhibited growth of these fungi by $48.4,55.752 .4 \%$, respectively.

\section{B) Antagonistic fungi}

Data in Tab. 4 shows that all the tested fungal species, Trichoderma sp., Aspergillus sp. and Penicillium sp. were 
Tab. 2. Varietal response of seven chickpea cultivars towards the tested fungi, greenhouse experiment

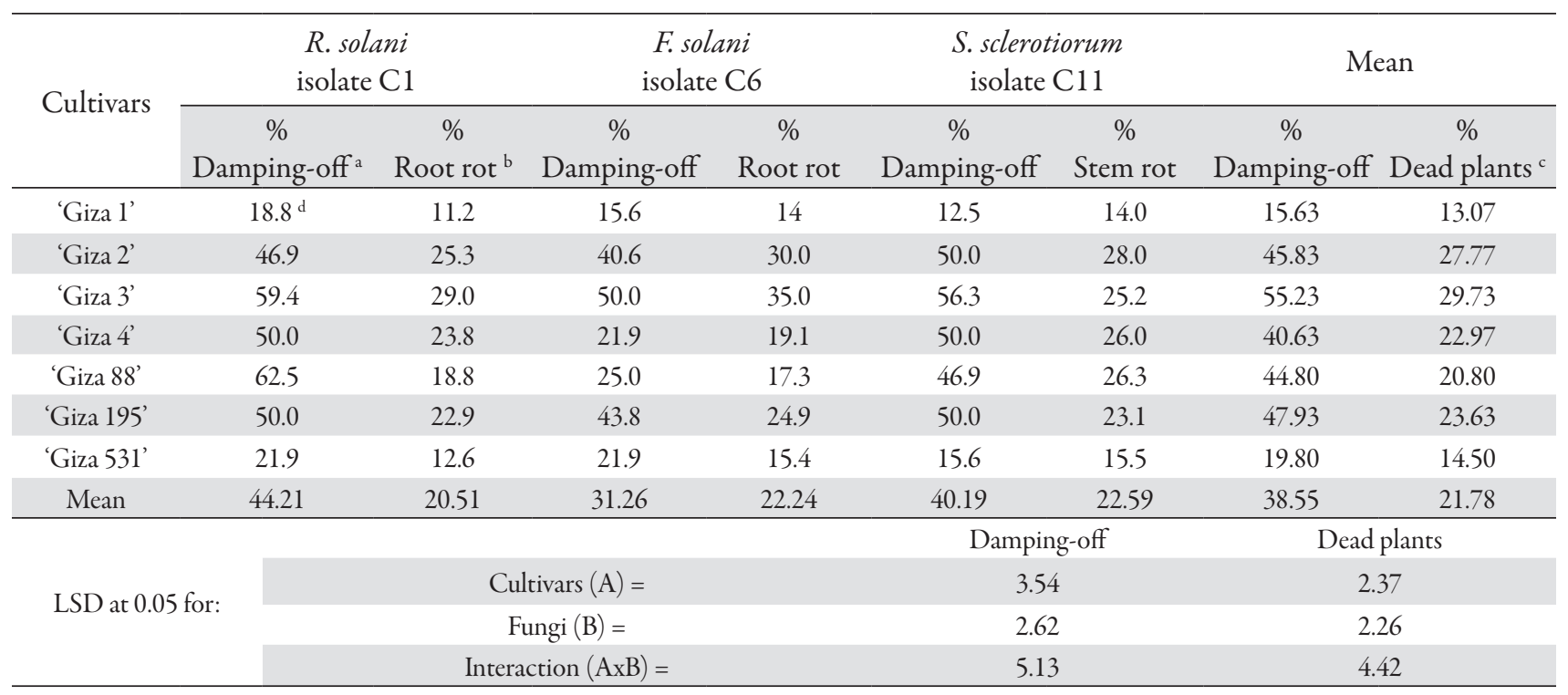

${ }^{\mathrm{a}}$ Assessed 30 days after sowing and ${ }^{\mathrm{b}}$ assessed 90 days after sowing; ${ }^{\mathrm{c}}$ Dead plants, \% due to infection by root rot and/or stem rot; ${ }^{\mathrm{d}}$ Values are means of 4 replicates

Tab. 3. In vitro antagonistic action between the bacterial isolates and the tested fungi

\begin{tabular}{lcccccc}
\hline & \multirow{2}{*}{ Bacteria isolates } & & \multicolumn{3}{c}{ \% Inhibition } \\
\cline { 4 - 6 } & & & R. solani & F. solani & S. sclerotiorum & Mean \\
\hline 1 & Bacillus subtilis & (BSM1) & $40.2^{\text {a }}$ & 53.5 & 50.1 & 47.93 \\
2 & B. subtilis & (BSM2) & 32.4 & 22.9 & 35.1 & 30.13 \\
3 & B. subtilis & (BSM3) & 24.3 & 28.4 & 33.0 & 28.57 \\
4 & B. megaterium & (BMM4) & 33.2 & 43.2 & 39.2 & 38.53 \\
5 & B. megaterium & (BMM5) & 48.4 & 55.7 & 52.4 & 52.17 \\
6 & B. cereus & (BCM6) & 8.5 & 12.4 & 10.4 & 10.43 \\
7 & B. cereus & (BCM7) & 10.3 & 21.2 & 25.1 & 18.87 \\
\hline & B. cereus & (BCM8) & 28.3 & 29.4 & 33.0 & 30.23 \\
\hline
\end{tabular}

a Values are means of 4 replicates

Tab. 4. In vitro antagonistic action between the fungal isolates and the tested fungi

\begin{tabular}{lcccccc}
\hline & \multirow{2}{*}{ Fungi isolates } & & \multicolumn{3}{c}{ \% Inhibition } \\
\cline { 4 - 7 } & & & R. solani & F. solani & S. sclerotiorum & Mean \\
\hline 1 & Trichoderma viride & (TVM1) & $40.1^{\text {a }}$ & 50.1 & 55.2 & 48.47 \\
2 & T. viride & (TVM2) & 68.2 & 75.1 & 70.4 & 71.23 \\
\hline 3 & T. viride & (TVM3) & 58.1 & 65.0 & 52.2 & 58.43 \\
\hline 4 & T. harzianum & (TVM4) & 62.4 & 73.5 & 66.8 & 67.57 \\
\hline 5 & T. harzianum & (TVM5) & 42.7 & 50.1 & 54.0 & 48.93 \\
\hline 7 & Aspergillus sp & (AM7) & 30.0 & 35.4 & 33.4 & 32.93 \\
8 & Aspergillus sp & (AM8) & 40.5 & 49.4 & 47.1 & 45.67 \\
9 & Penicillium sp & (PM9) & 25.4 & 33.4 & 35.0 & 31.27 \\
\hline
\end{tabular}

${ }^{a}$ Values are means of 4 replicates

found to be antagonistic to the pathogenic fungi, based on the reduction in growth area of pathogens. Trichoderma spp. were account for more than $50 \%$ of the rhizospheric fungi. T. viride isolate TVM2 and T. harzianum isolate
THM4 were found to be the most potent antagonistic fungi to all tested pathogens. Trichoderma viride isolate TVM2 reduced the growth of $R$. solani, F. solani and $S$. sclerotiorum with $68.2,75.1$ and $70.4 \%$, respectively. 
Also, T. harzianum isolate THM4 was able to reduce growth of R. solani, F. solani and S. sclerotiorum with 62.4, 73.5 and $66.8 \%$, respectively.

The highest antagonistic fungal isolates, i. e. T. viride (isolate TVM2) and T. harzianum (isolate THM4) and, among the bacterial isolates, B. subtilis (isolate BSM1) and B. megaterium (isolate BMM5) were selected to study the role of these isolates in biological control of damping-off, root and stem rot diseases in chickpea plants under greenhouse and field conditions.

Effects of seed treatment with biocontrol agents on chickpea damping-of and root and /or stem rot diseases under greenhouse conditions

Data in Tab. 5 show that all the antagonistic isolates were able to cause significant reduction to damping-off and root and/or stem rot diseases. All antagonistic isolates isolated from chickpea rhizosphere gave high protection against all the tested pathogens than the commercial biocide product (Rhizo-N). Treatment chickpea seeds with T. viride isolate TVM1 were the most effective to reduce damping-off, and root and/or stem rot diseases in case of soil infested with $R$. solani, $F$ solani and $S$. sclerotiorum. Seed treatment with $B$. megaterium isolate BMM2 came next T. viride. B. subtilis isolate BSM1 gave the lowest protection against $R$. solani and $F$. solani, while T. harzianum isolate THM4 recorded the lowest protection against infection by $S$. sclerotiorum.

Integrated control of damping-off, root and/or stem rot diseases in chickpea plants under field conditions

Data of the previous experiments, i. e. the in vitro antagonism and in the greenhouse experiment indicated that B. subtilis isolate BSM1, B. megaterium isolate BMM5, T. viride isolate TVM2 and T. harzianum isolate THM4 were the most effective antagonistic microorganisms against the root and stem rot pathogens.
These isolates were used in the integrated disease management programs to control root and stem rot diseases in chickpea plants.

Data presented in Tab. 6 clearly show that all tested biological agents significantly decreased damping-off, root and stem rot compared to the untreated plants (control) at all sowing dates. The efficacy of bioagents significantly affected by sowing dates. In this regard, sowing at $1^{\text {st }} \mathrm{No}$ vember in both seasons, gave the highest effect in reducing damping-off, root and/or stem rot. In addition, $B$. megaterium (isolate BMM5) and T. viride (isolate TVM2) were the most effective for controlling damping-off and root and/or stem rot in both seasons. In sowing date of $1^{\text {st }} \mathrm{No}$ vember, $B$. megaterium and $T$. viride reduced damping-off from $17.95 \%$ in control to 3.75 and $6.2 \%$ (average of both seasons), respectively and reduced root and/or stem rot from $10.45 \%$ to 2.7 and $2.55 \%$, respectively.

Seed treated with Rhizo-N recorded the lowest protestant against damping-off, root and stem rot diseases. In control treatment, sowing dates showed significant effect on damping-off and root /stem rot diseases in chickpea plants. The highest average of damping-off on chickpea plants occurred at sowing date $1^{\text {st }}$ October in both seasons (21.95\%) while sowing at $1^{\text {st }}$ December recorded the lowest damping-off (15.85\%). Also, the same trend was obtained in case of root and stem rot $(16.0 \%$ in sowing date at $1^{\text {st }}$ October and $9.4 \%$ in sowing date at $1^{\text {st }}$ December).

On the other hand, the reduction in both damping-off and root and/or stem rot was significantly reflected on the produced seed yield and the produced seed yield was affected significantly with sowing dates. In this respect, seeds previously treated with $T$. viride produced the highest seed yield in all sowing dates followed by seeds treated with $B$. megaterium. For sowing at $1^{\text {st }}$ November, seeds treated with $T$. viride and/or B. megaterium resulted average seed yield, being 708.17 and $681.56 \mathrm{~kg} / \mathrm{fed}$. (average of both seasons), respectively compared to the control (517.31

Tab. 5. Effect of treatment chickpea seeds (cv. 'Giza 3') with various bioagents on damping -off and root rot diseases caused by the tested fungi, greenhouse experiment

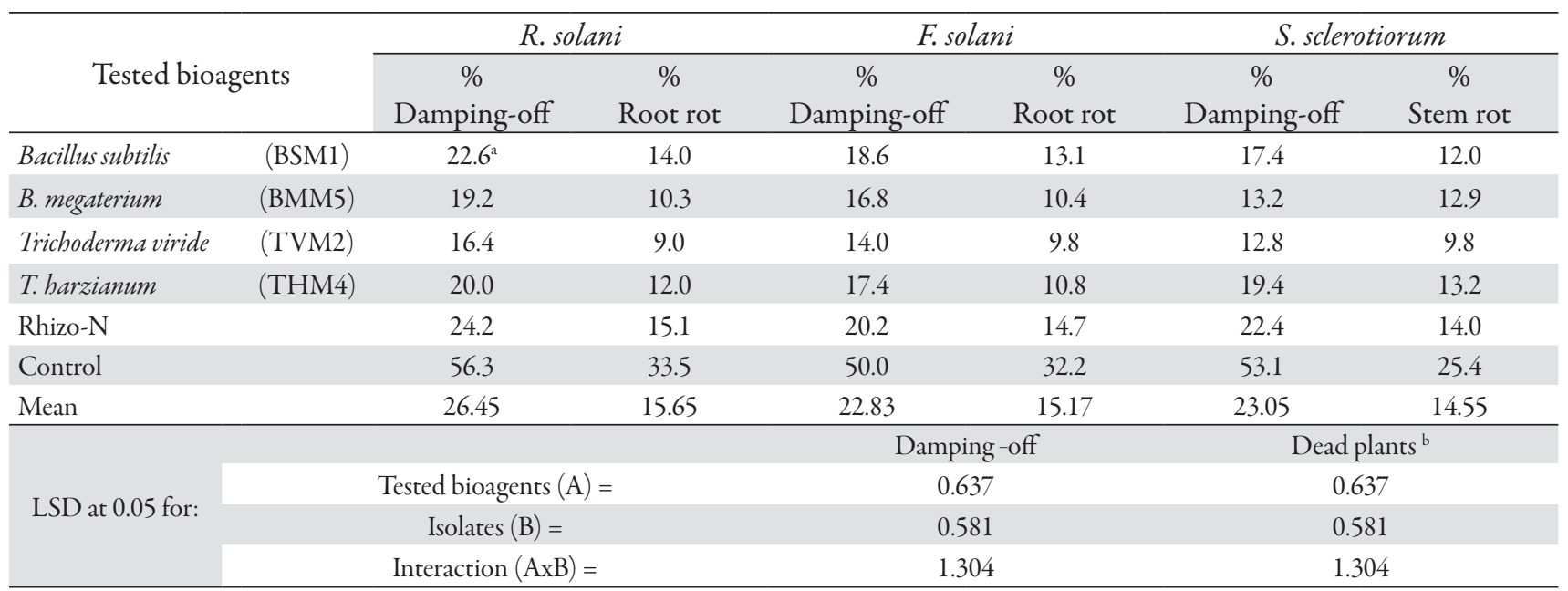

${ }^{a}$ Values are means of 4 replicates; ${ }^{b}$ Dead plants, \% due to infection by root rot and/or stem rot 
86

Tab. 6. Effect of treatment chickpea seeds (cv. 'Giza 3') with bioagents on damping-off, root and stem rot and seed yield during 2008-2009 and 2009-2010 growing seasons under field conditions at New Valley governorate

\begin{tabular}{|c|c|c|c|c|c|c|c|c|c|c|}
\hline \multirow[t]{2}{*}{ Sowing Date } & \multirow{2}{*}{$\begin{array}{c}\text { Tested } \\
\text { Bioagents }\end{array}$} & \multicolumn{3}{|c|}{$\begin{array}{c}\% \\
\text { Damping-off }\end{array}$} & \multicolumn{3}{|c|}{$\begin{array}{c}\% \\
\text { Dead plants } \\
\end{array}$} & \multicolumn{3}{|c|}{$\begin{array}{c}\text { Total seed yield } \\
\left(\mathrm{Kg} \mathrm{fed}^{-1}\right)\end{array}$} \\
\hline & & 2008-09 & $2009-10$ & Mean & 2008-09 & $2009-10$ & Mean & 2008-09 & $2009-10$ & Mean \\
\hline \multirow{7}{*}{$\begin{array}{c}1 \stackrel{\mathrm{st}}{ } \\
\text { October }\end{array}$} & BSM1 & $16.4^{\mathrm{b}}$ & 15.2 & 15.80 & 7.9 & 10.1 & 9.00 & 535.51 & 511.41 & 523.46 \\
\hline & BMM5 & 11.6 & 11.4 & 11.50 & 6.4 & 7.3 & 6.85 & 584.31 & 543.20 & 563.76 \\
\hline & TVM2 & 10.2 & 10.4 & 10.30 & 5.6 & 5.9 & 5.75 & 593.02 & 566.73 & 579.88 \\
\hline & THM4 & 15.2 & 14.3 & 14.75 & 9.9 & 10.2 & 10.05 & 520.20 & 508.81 & 514.51 \\
\hline & Rhizo-N & 17.4 & 16.3 & 16.85 & 10.5 & 10.9 & 10.70 & 513.09 & 500.00 & 506.55 \\
\hline & Control & 25.2 & 18.7 & 21.95 & 14.5 & 17.5 & 16.00 & 445.21 & 426.80 & 436.01 \\
\hline & Mean & 16.00 & 14.38 & 15.19 & 14.79 & 14.99 & 14.89 & 531.89 & 509.49 & 520.69 \\
\hline \multirow{7}{*}{$\begin{array}{c}1 \stackrel{\text { st }}{\text { November }} \\
\text { Nom }\end{array}$} & BSM1 & 8.6 & 9.1 & 8.85 & 4.5 & 5.3 & 4.90 & 664.05 & 653.22 & 658.64 \\
\hline & BMM5 & 3.2 & 4.3 & 3.75 & 2.6 & 2.8 & 2.70 & 692.01 & 671.14 & 681.56 \\
\hline & TVM2 & 5.9 & 6.2 & 6.20 & 2.5 & 2.6 & 2.55 & 714.33 & 702.00 & 708.17 \\
\hline & THM4 & 7.4 & 7.2 & 7.30 & 6.4 & 7.3 & 6.85 & 660.56 & 653.22 & 656.89 \\
\hline & Rhizo-N & 8.2 & 9.0 & 8.60 & 7.3 & 8.3 & 7.80 & 621.40 & 605.87 & 613.64 \\
\hline & Control & 19.5 & 16.4 & 17.95 & 9.7 & 11.2 & 10.45 & 525.31 & 509.30 & 517.31 \\
\hline & Mean & 9.38 & 8.7 & 8.78 & 5.5 & 6.25 & 5.86 & 646.28 & 632.46 & 639.37 \\
\hline \multirow{7}{*}{$\begin{array}{c}1 \stackrel{\text { st }}{\text { December }}\end{array}$} & BSM1 & 14.3 & 13.9 & 14.10 & 6.4 & 5.4 & 5.90 & 454.32 & 425.10 & 439.71 \\
\hline & BMM5 & 14.3 & 11.2 & 12.75 & 5.4 & 6.3 & 5.85 & 481.23 & 448.39 & 464.81 \\
\hline & TVM2 & 14.3 & 12.3 & 13.30 & 7.1 & 7.4 & 7.25 & 423.37 & 401.30 & 412.34 \\
\hline & THM4 & 14.3 & 12.3 & 13.30 & 7.1 & 7.4 & 7.25 & 423.37 & 401.30 & 412.34 \\
\hline & Rhizo-N & 14.3 & 12.4 & 13.35 & 6.2 & 7.1 & 6.65 & 410.31 & 394.85 & 402.58 \\
\hline & Control & 17.3 & 16.4 & 15.85 & 9.2 & 9.6 & 9.40 & 375.40 & 359.53 & 367.49 \\
\hline & Mean & 14.8 & 12.75 & 13.78 & 6.9 & 7.2 & 7.05 & 444.87 & 415.23 & 430.05 \\
\hline \multirow{5}{*}{\multicolumn{2}{|c|}{ LSD at 0.05 for: }} & \multicolumn{5}{|c|}{ Damping-off } & Dead pla & \multicolumn{3}{|c|}{ Total seed yield } \\
\hline & & \multicolumn{3}{|c|}{ Sowing date $(\mathrm{A})=$} & \multicolumn{2}{|l|}{1.272} & 0.493 & \multicolumn{3}{|c|}{6.50} \\
\hline & & \multicolumn{3}{|c|}{ Tested Bioagents $(\mathrm{B})=$} & \multicolumn{2}{|l|}{0.799} & 0.483 & \multicolumn{3}{|c|}{23.87} \\
\hline & & \multicolumn{3}{|c|}{ Seasons $(\mathrm{C})=$} & \multicolumn{2}{|l|}{ ns } & $*$ & \multicolumn{3}{|c|}{$*$} \\
\hline & & \multicolumn{3}{|c|}{ Interaction $(\mathrm{AxBxC})=$} & \multicolumn{2}{|l|}{2.001} & 1.024 & \multicolumn{3}{|c|}{29.04} \\
\hline
\end{tabular}

${ }^{a}$ Dead plants, \% due to infection by root rot and/or stem rot; ${ }^{\mathrm{b}}$ Values are means of 4 replicates; BSM1= Bacillus subtilis, BMM5 = B. megaterium,

TVM2 $=$ Trichoderma viride, THM4 $=$ T. harzianum

$\mathrm{kg} /$ fed.). Chickpea seeds treated with Rhizo-N recorded the lowest seed yield compared the other bioagents. Also, the obtained data showed that the sowing dates to affected significantly the seed yield so that in treated seeds or untreated seeds. Sowing at $1^{\text {st }}$ December recorded the lowest seed yield $\left(367.49 \mathrm{~kg} / \mathrm{fed}\right.$. in average), while sowing at $1^{\text {st }}$ November recorded the highest seed yield $(517.31 \mathrm{~kg} / \mathrm{fed}$. in average). It was found sowing at the late date, in case of control, recorded the lowest damping-off, root and stem rot diseases, but scored less the amount of seed yield.

\section{Discussion}

During this investigation, eleven fungal isolates were isolated from chickpea roots collected from different locations in New Valley governorate. The isolated fungi were identified as Rhizoctonia solani, Fusarium solani and Sclerotinia sclerotiorum. In pathogenicity tests, all the isolated fungi were pathogenic to chickpea plants cv. 'Giza 3' with different degrees of disease severity. These results are in agreement with those reported by Kaur et al. (2007); Khalil (2007) and Siddiqui and Akhtar (2007).
The obtained data indicated that only 'Giza 1' was resistant to infection with any of the tested fungi and 'Giza 531' was moderately resistant, while the other cultivars were highly susceptible (Hassanein et al., 1997; Rahhal et al., 2000). Khalil (2007) reported that chickpea cv. 'Giza 1 ' proved to be the most resistant against damping -off and root and/or stem rot caused by F. solani, S. sclerotiorum. While cvs. 'Giza 2', 'Giza 3' and 'Giza 4' were susceptible to all the tested fungi.

In vitro studies indicated that antagonistic fungi and bacteria inhibited the growth of the tested fungi with different degrees of inhibition. Many investigators reported that many Trichoderma spp. and Bacillus spp. are able to inhibit growth of the tested fungi (Prasad et al., 2002; Siddiqui and Akhtar, 2007; Sallam et al., 2008; Zheng and Sinclair, 2000). Elad (1996) stated that mechanisms of the antagonism of Trichoderma spp. and Bacillus spp. against different pathogens may be due to mycoparasitism, competition and antibiosis.

Under greenhouse conditions, all the tested antagonistic isolates were able to cause significant reduction of damping-off, root and/or stem rot diseases in chickpea 
plants. T. viride (isolate TVM2) and B. megaterium (isolate BMM5) proved to be the most effective isolates for controlling the diseases.

These antagonistic isolates were selected to treat seeds of the resistant cultivar 'Giza 1' which were sown in three sowing dates to be an integrated control program to reduce infection by damping-off, root and/or stem rot diseases under field conditions. Data summarized that all tested antagonistic isolates caused significant reduction of damping-off and root and/or stem rot diseases under field conditions in all sowing dates

The reduction in disease severity under field conditions was reflected on seed yield. Plants grown from seeds treated with biocontrol agents produced seed yield greater than untreated ones. Seeds previously treated with $T$. viride produced the highest seed yield in all sowing dates followed by seeds treated with B. megaterium. Seed yield was significantly affected with sowing dates in treated seeds or untreated seeds, where sowing in first of November gave the highest seed yield compared with the other sowing dates. These results are relatively similar to those obtained by Prasad et al. (2002) who tested two antagonistic fungi, T. harzianum (PDBCTH-10) and T. viride (PDBCTV) against wilt (Fusarium oxysporum f. sp. ciceri) and wet root rot (Rhizoctonia solani) diseases of chickpea in the field. Zheng and Sinclair (2000) showed that there was a significant positive correlation $(\mathrm{r} 2=0.78)$ between root colonization by $B$. megaterium strain B153-2-2 or its mutants and suppression of Rhizoctonia root rot of soybean plants. Landa et al. (2004) studied the effect of sowing date, host resistance and biological control on spread of Fusarium wilt in chickpea plants. They found that the main effects of sowing date, partially resistant genotypes, and biocontrol agents caused a reduction in the rate of epidemic development over time, a reduction of disease intensity, and an increase in chickpea seedling emergence. Chickpea seed yield was influenced by all three factors in the study. The increase in chickpea seed yield was the most consistent effect of the biocontrol agents. However, the effect was primarily influenced by sowing date, which also determined disease development. Sallam et al. (2008) reported that the tested formulations of Trichoderma spp. proved to be effective for controlling $R$. solani and $F$. oxysporum, the causal agents of bean damping-off and wilt diseases, respectively under greenhouse and artificially infested field conditions and also enhanced green yield compared to infection control.

There are many mechanisms suggested to clarify the role of antagonistic organisms in suppression of growth pathogens and thus to control diseases. Their action could be through antibiosis (Walker et al., 1998), mycoparasitism (Haran et al., 1996). The competition for nutrients and/or space (Inbar et al., 1994). Also, the other mechanisms involved are induction of resistance in plants through increased of oxidative enzymes, i.e. polyphenol oxidase, peroxidase, enhanced lignifications (Jetiyanon et al., 1997), induction of pathogeneses related protein (PR1 ), chitinase and $\beta, 1-3$, gluconase in addition to increase salicylic acid (SA) level in plants (De Meyer et al., 1998).

The increase of seed yield obtained in this study, could be attributed to the effect of biocontrol agents as plant growth promoters (Naseby et al., 2000). Yuming et al. (2003) reported that three Bacillus strains, B. subtilis NEB 4 and NEB5 and B. thuringiensis NEB17 provided increases in nodule number, nodule weight, shoot weight, root weight, total biomass, total nitrogen and grain yield of soybean plants.

In summary, it could be concluded that management of damping-off, root and/or stem diseases of chickpea could be based on strategies that integrate several control measures in the form of selected chickpea resistant cv. 'Giza 1 ' and treated with $T$. viride (TVM2) or B. megaterium (BMM5) and sown in first of November lead to decrease of damping-off, root and/or stem rot diseases and increase of seed yield under field conditions. Also, the obtained bioagents isolated from chickpea rhizosphere proved to be a commercial biocide product, but this needs further studies on these isolates before using in the biological control programs.

\section{References}

Anonymous (2005). Food and Agriculture Organization of the United Nations. FAO Production Yearbook, Rome, Italy.

Bailey BA, Bae H, Strem MD, Crozier J, Thomas SE, Samuels GJ, Vinyard BT, Holmes KA (2008). Antibiosis, mycoparasitism, and colonization success for endophytic Trichoderma isolates with biological control potential in Theobroma cacao. Bio Control 46: 24-35.

Barnett HL, Hunter BB (1986). Illustrated Genera of Imperfect Fungi. $4^{\text {th }}$ Ed., Macmillan Publishing Co., New York.

Booth C (1985). The genus Fusarium. Kew, Surrey Commonwealth Mycological Institute, 2를 Ed., p. 237.

De Meyer G, Bigirimana J, Elad Y, Hofte M (1998). Induced systemic resistance in Trichoderma harzianum T39 biocontrol of Botrytis cinerea. Eur J Plant Pathol 104:279286.

Dhingra OD, Sinclair JB (1985). Basic Plant Pathology Methods. CRC, Boca Raton, Florida, USA.

Elad Y (1996). Mechanisms involved in the biological control of Botrytis cinerea incited diseases. Eur J of Plant Pathol 102(8):719-732.

Fokemma NJ (1973). The role of saprophytic fungi in antagonism against Drechslera sorokiniana (Helminthosporium sativum) on agar plates and on rye leaves with pollen. Physiol Plant Pathol 3:195-205.

Gomez KA, Gomez AA (1984). Statistical Procedures for Agricultural Research. A. Wiley-Interscience Publication. New York, p. 678.

Haran S, Schickler H, Chet I (1996). Molecular mechanisms 
88 of lytic enzymes involved in the biocontrol activity of Trichoderma harzianum. Microbiol 142:2321-2331.

Hassanein AM, El-Garhy AM, Mekhemar GAA (2006). Symbiotic nitrogen fixation process in faba bean and chickpea as affected by biological and chemical control of root-rot. J Agric Sci Mansoura Univ 31(2):963-980.

Hassanein AM, El- Morsy GA, Abou-Zied NM, Mahmoud Samia A (1997). Integrated control of root rot /wilt diseases in faba bean, lentil and chickpea. Egypt J Agric Res 75(3):543-550.

Inbar J, Abramshy D, Cohen DS, Chet I (1994). Plant growth enhancement and disease control by Trichoderma harzianum in vegetable seedlings grown under commercial conditions. Europ J Plant Pathol 100:337-346.

Jetiyanon K, Tuzun S, Kloepper JW (1997). Lignifications, peroxidase reaction and superoxidase dismutase as early plant defense associated with PGPR- mediated induced systemic resistance, p. 265-268. In: Ogoshi A, Kobayashi K, Homma Y, Kodama F, Kodo N, Akino S (Eds.). 'Plant Growth Promoting Rhizobacteria. Present Status and Future Prospects". Proc $4^{\text {th }}$ Internat Sapporo, Japan.

Jiménez-Díaz RM, Porta-Puglia A, Tivoli B (1998). New approaches in the integrated management of legume diseases: Toward sustainable crop health, pp 89-93. In: $3^{\text {rd }}$ European Conference on Grain Legumes. Opportunities for High Quality, Healthy and Added-value Crops to Meet European Demands. European Association for Grain Legumes, Valladolid, Spain.

Kaur R, Singh RS, Alabouvette C (2007). Antagonistic activity of selected isolates of fluorescent Pseudomonas against Fusarium oxysporum f. sp. ciceri. Asian J of Plant Sci 6(3):446-454.

Khalil MSM (2007). Studies on Some Chickpea (Cicer arietinum L.) Fungal Diseases. M.Sc. Thesis, Fac. Agric. Minia Univ. Egypt.

Landa BB, Navas-Cortés JA, Jiménez-Díaz RM (2004). Integrated management of Fusarium wilt of chickpea with sowing date, host resistance, and biological control. Phytopathol 94:946-960.

Landa BB, Navas-Cortés JA, Hervás A, Jiménez-Díaz RM (2001). Influence of temperature and inoculum density of Fusarium oxysporum f. sp. ciceris on suppression of Fusarium wilt of chickpea by rhizosphere bacteria. Phytopathol 91:807-816.

Larkin RP, Fravel DR (1998). Efficacy of various fungal and bacterial biocontrol organisms for control of Fusarium wilt of tomato. Plant Dis 82: 1022-1028.
Liu L, Kloepper JW, Tuzun S (1995). Introduction of systemic resistance in cucumber against Fusarium wilt by plant growth-promoting rhizobacteria. Phytopathol 85:695-698.

Naseby DC, Pascual JA, Lynch JM (2000). Effect of biocontrol strains of Trichoderma on plant growth, Pythium ultimum populations, soil microbial communities and soil enzyme activities. J App Microbiol 88:161-169.

Nene Y, Reddy MV (1987). Chickpea diseases and their control. Pp 233-270. In: Saxena MC, Singh KB (Eds.). The Chickpea, Commonwealth Agricultural Bureaux International, Oxon, UK, 320.

Prasad RD, Rangeshwaran R, Anuroop CP, Rashni HJ (2002). Biological control of wilt and root rot of chickpea under field conditions. Ann Pl Prot Sci 10(1):72-75.

Rahhal MMH, Bastawisy MH, Ismail IA, El-Awadi FA, Heweidy MA (2000). Evaluation of some chickpea cultivars and entries to damping-off disease under greenhouse and field conditions. Proc. $9^{\text {th }}$ Congress of the Egypt. Phytopathol Soc. Giza, Egypt, p. 385-392.

Sallam Nashwa MA, Abo-Elyousr KAM, Hassan MAE (2008). Evaluation of Trichoderma species as biocontrol agent for damping-off and wilt diseases of Phaseolus vulgaris L. and efficacy of suggested formula. Egypt J Phytopathol 36(12):81-93.

Siddiqui ZA, Akhtar MS (2007). Biocontrol of a chickpea root rot disease complex with phosphate- solubilizing microorganisms. J of Plant Pathology 9(1):67-77.

Sneath PHA, Mair NS, Sharpe ME, Holt JG (1986). Bergeys Manual of Systemic Bacteriology. Williams and Wilkins Co., Baltimore 1123.

Turner D, Kovacs W, Kuhis K, Lieckfeldt EW, Peter B, Arisan Atac I, Strauss J, Samuels G J, Bomer T, Kubicek C (1998). Biogeography and phenotypic variation in Trichoderma sect. longibraclatum and associated Hypocrea species. Mycol Res 101:449-549.

Walker R, Powell AA, Seddon B (1998). Bacillus isolates from the spermosphere of peas and French beans with antifungal activity against Botrytis cinerea and Pythium species. J Appl Microbiol 84:791-801.

Yuming B, Xiaomin Z, Smith DL (2003). Enhanced soybean plant growth resulting from coinoculation of Bacillus strains with Bradyrhizobium japonicum. Crop Sci 43:1774-1781.

Zheng XY, Sinclair JB (2000). The effects of traits of Bacillus megaterium on seed and root colonization and their correlation with the suppression of Rhizoctonia root rot of soybean. Bio Control 45:223-243. 